\title{
University of
}

Peck, Frank and Cabras, Ignazio (2009) Off-shoring in the contact centre industry and employment in the North West of England. Service Industries Journal, 29 (2). pp. 173-184.

Downloaded from: http://insight.cumbria.ac.uk/id/eprint/2001/

Usage of any items from the University of Cumbria's institutional repository 'Insight' must conform to the following fair usage guidelines.

Any item and its associated metadata held in the University of Cumbria's institutional repository Insight (unless stated otherwise on the metadata record) may be copied, displayed or performed, and stored in line with the JISC fair dealing guidelines (available here) for educational and not-for-profit activities

provided that

- the authors, title and full bibliographic details of the item are cited clearly when any part of the work is referred to verbally or in the written form

- a hyperlink/URL to the original Insight record of that item is included in any citations of the work

- the content is not changed in any way

- all files required for usage of the item are kept together with the main item file.

\section{You may not}

- sell any part of an item

- refer to any part of an item without citation

- amend any item or contextualise it in a way that will impugn the creator's reputation

- remove or alter the copyright statement on an item.

The full policy can be found here.

Alternatively contact the University of Cumbria Repository Editor by emailing insight@cumbria.ac.uk. 


\title{
OFF-SHORING IN THE CONTACT CENTRE INDUSTRY AND EMPLOYMENT IN THE NORTHWEST OF ENGLAND
}

\author{
Frank Peck, Research Director, CRED, Uclan \\ Ignazio Cabras, Research Assistant, CRED, Uclan \\ Centre for Regional Economic Development \\ Lancashire Business School \\ University of Central Lancashire \\ Preston PR1 3HE \\ fpeck@uclan.ac.uk \\ icabras@uclan.ac.uk \\ 01772895241
}

\begin{abstract}
The significance of contact centre employment has recently been the subject of renewed debate in regional policymaking which has been driven by media comment on the threat of off-shoring. Despite these concerns, empirical research on the scale of such activities in regions is limited. This article reviews available data on contact centre employment in the subregions of North-West England. The evidence appears to show continued growth in the number of contact centres and employment totals. The concluding section reconsiders the significance of contact centres for Regional Economic Strategies that focus on developing high value-added activities.
\end{abstract}

Key words:

Contact Centres, North West England, Employment, Off-Shoring, Regional Development 


\section{INTRODUCTION}

Recent policy debates concerning the impacts of the phenomenon of "off-shoring" have focused attention once again on the contribution that contact centres make towards the UK economy and its constituent regions. Business and media coverage of economic changes affecting contact centres over the past two years has drawn attention to the trend towards off-shoring to low labour cost locations particularly to the Indian subcontinent [Newing, 2004]. The impression given by commentators is that this trend has been at the expense of jobs in the UK. As one example, the Managing Director of ICT Europe has stated that '2004 will be viewed as the year of the off-shore contact centre, the year when off-shoring became a truly widely adopted business strategy. Under strong pressure to control costs, it is no longer a question of if you should take contact centre work off-shore, but when and how' [Puttock, 2004].

At present, there is only limited independent academic research to test the assumption that these recent changes have led directly to job losses in the UK. Existing research on processes of change in call centres and regional development is fairly comprehensive for the period up to the late 1990s [Richardson and Marshall 1996; Richardson et al., 2000; Richardson and Belt 2001; Bishop et al., 2003]. More recently, some interesting attempts have been made to analyse the national situation. Studies have shown, for instance, that the UK continues to display a growing trade surplus in business services and that most "outsourcing" is still within the UK and not off-shore [Abramovsky et al., 2004; Abramovsky and Griffith 2005]. However, there is little recent research on the effects of corporate reorganisation on employment in contact centres at the regional scale. 
The purpose of this article is to examine available evidence of recent patterns of change in contact centre employment and to consider the significance and role of contact centres for the achievement of regional economic strategies. Previous research has drawn attention to policy debates concerning the quality of jobs and levels of pay in contact centres [Richardson and Belt, 2001; Belt and Richardson 2005]. More recent discussion of the threats to call centre employment associated with offshoring has perhaps added to scepticism concerning the extent to which contact centres may provide sustainable employment in peripheral regions in future. These policy issues are discussed in the context of recent evidence of change in employment in contact centres in the North-West Region of England.

\section{OFF-SHORING, THE CONTACT CENTRE INDUSTRY AND THE 'EXPORT OF UK JOBS’?}

It is widely recognised that contact centre activities are highly exposed to off-shoring practices since the nature of the business allow operators to work in the remote locations without necessarily affecting the nature of the services provided. New information technologies have improved the efficiency and speed of interchange of data on competitive global networks which reduces the costs of calls and makes possible the creation of contact centre businesses that serves different geographical areas across the world [Richardson and Marshall, 1999]. It is also the case that offshoring affects the UK service sector in particular as it is a major exporter of services and will therefore be sensitive to shifts in international competitiveness. These 
debates and issues have inevitably raised the question about the threat of job losses within UK call centres associated with off-shoring [DTI, 2004].

However, a company's decision to locate some (or all) of its operations in another geographical area involves complex factors that are often overlooked in media coverage. Contact centre activities are not homogenous as they can be found in a wide variety of product-markets and across all sectors of the economy. Business conditions will clearly vary in terms of such factors as cost pressures, levels of dependence on specialist forms of knowledge in the UK workforce and the need for close linkage with other industries and business networks. Contact activities that operate in an industry with recognised global products and standards (as in some areas of insurance or banking) might well respond to sluggish growth in revenue by considering offshore locations. However, in some other product markets, as for some UK utilities, high cost pressure may perhaps be overridden by the value of local knowledge and worries about loss of service quality arising from off-shoring. In these circumstances, other strategies based on spatial restructuring within the UK are available to businesses experiencing competitive pressures. Significant cost saving, for instance, may be generated by consolidation of activities into larger contact centres to gain economies of scale or by outsourcing within the UK.

The Department of Trade and Industry [DTI, 2004:131] argues that the main reason that 'businesses consider off-shoring contact centres is to reduce the $60-70 \%$ of their operating expenses which are spent on agent salaries'. It is also suggested that agentdriven expenses can reach $£ 8 m$ (per year) with respect to a 500-seat contact centre. At labour rates current at the time, it was suggested that a 50-seat contact centre move 
to India would be able to achieve payback within three months. The DTI also draws attention to levels of flexibility in the labour market and the fact that performances in terms of average speed of answered calls can also be increased through off-shoring. Their report also suggests that there are higher levels of job satisfaction reported in India compared to the UK which produces low attrition levels and reduces recruitment and retention problems.

While the trend to off-shoring of contact centres has attracted considerable attention, it is difficult to obtain precise data on the number of businesses that have moved abroad. It is also problematic to associate off-shoring with specific closures and job losses in the UK. This is partly due to the problems with official data and industry classifications. But even if this data made it easier to identify contact centre employment, it would not be simple to trace these labour market impacts at the micro level. There will be time lapses in the process of restructuring which allow other changes to occur that obscure the effects of off-shoring. Contact centre workers, for instance, may be offered positions in other departments in the same businesses and this type of information on redeployment is not freely available. Heckley [2005: 377] indeed notes that the definition of an 'exported job' is 'difficult to define in a dynamic economy where change occurs simultaneously on a number of dimensions'; a business that is involved in moving contact functions offshore is highly likely to be engaged in a widespread restructuring that affects other operations and locations in the UK. Businesses may also be simultaneously engaged in outsourcing as well as off-shoring and disaggregating the labour market impacts of off-shoring would be difficult to achieve. 
While most attention has been given to contact centre businesses which outsource offshore, there are cases of businesses reverting back to a UK base. The DTI [2004:136] documents the case of Shop Direct which opened a contact centre in Bangalore in 2002. These cases are given less attention partly because of concerns of companies about negative images arising from perceived 'failure' of a business decision. In this particular instance, Shop Direct officials stated that the Bangalore investment had been undertaken on a trial basis, but that 'the level of customer service was not up to the standard the company wanted'. The company retrenched its contact activities to its existing centres at six locations across the UK.

This example suggests that there are real risks associated with off-shoring connected with the response of the market, political instabilities in overseas countries and "hidden" costs that arise in coordinating processes over long distances and possible reductions in service quality. The DTI [2004] also reports, for instance, that while there may be cost savings of up to twelve percent through off-shoring, in some cases agents in the UK may answer as many as twenty-five percent more calls and resolve the issues raised on the first call more frequently. Negative experiences arising from repeat calls may then have impacts upon customers who might consider migrating to competitors for the same service. These effects may, of course, vary considerably depending on the nature of the service, effectiveness of training and the significance of local knowledge in dealing with the customer [CM Insight, 2001].

Even on the issue of labour costs themselves, where the argument might appear relatively clear cut, recent reports suggest that cost management in off-shore contact centres may be a growing problem over time as labour rates between global contact 
centre locations converge. Datamonitor [2005], for instance, has suggested that call centre agent benefits are rising in India and Malaysia as local managers are working to reduce attrition rates. Despite these complexities, when jobs are created abroad following off-shoring, a common assumption is that this means aggregate job losses in UK and the NW region. While it is not possible to identify 'exported jobs' accurately using official UK employment data for reasons suggested previously, some information on patterns of change in businesses can be used to suggest the aggregate effects on employment totals.

\section{MEASURING REGIONAL CHANGE IN CONTACT CENTRE ACTIVITY}

Attempts to measure the contribution of the 'contact centre industry' to regional economies face considerable challenges in terms of definitions and data sources. While it can be counterproductive to engage in debate as to whether or not 'contact centres' constitute an industry in their own right, there are issues that affect our ability to measure their economic significance. Official statistics are constructed on the basis of classifications that contain assumption about what constitutes an 'industry', 'sector' 'skill' or 'occupation'. These classifications are updated periodically, but such changes tend to be minimal to avoid problems for analysis of trends over time. The difficult arises in that the Standard Industrial Classification (SIC) tends to be constructed around product-markets or specific types of services to end-users [Jones, 2003]. As contact centres deal with a very wide range of products and services, the economic significance of contact centre functions tends to be dispersed and largely 'invisible' in official statistics on regional employment that use SIC codes. 
Changes were last made to the SIC in 2003 in order to take account of the fact that new products, processes and industries emerge. These changes that were made following a UK consultation process have been outlined by Jones [2003] and these include a category for 'call centre activities' (SIC 74.86). For the first time, therefore, official data is published for contact centres although the data is for one year only so no time trend can be analysed. Table one shows that, according to this data, businesses that responded to the ABI in 2003 as 'call centre businesses' employed a total of 25,112 nationally of whom over one fifth $(5,346)$ were employed by businesses in the NW Region.

\section{(Table 1)}

While this data has 'official status' it should be treated with considerable caution. It is derived from a survey where managers are required to state the nature of their business as a basis for classification. In many cases, it is quite likely that survey respondents will describe the particular service that they deliver (e.g. insurance services) rather than the nature of the technology or the form of organisation that is used (call centre).

Partly due to these problems with data, recent work completed by ContactBabel [2004] attempted to cross-reference contact centre businesses with 'vertical markets'. This data has been assembled in the first instance from the UK Contact Centre Operations Directory that contained information on 2,800 businesses across the UK. Various sources were used to expand this source and new entries have been added. The authors exclude centres with under ten employees and in an unreported number of cases estimates have been made of 'numbers of seats' and employment. 
While aggregate data are described as 'approximations' and should not be considered as accurate down to single figures, the outcome of this research process demonstrates the potential levels of underestimation of contact centre employment found in official statistics for 2003. Contactbabel [2004] identified 4,825 contact centres across the UK regions, 540 of these located within the NW region (11\%). It is estimated that these activities generate as many as 846,000 jobs nationally of which around 132,000 are in the NW region (16\%). In terms of size structure, the North West has a higher proportion of medium and large size contact centre compared to national averages.

Until recently, there has been no means of providing independent corroborating evidence from other sources to verify the findings of ContactBabel. However, a recent publication produced by National Statistics and reported in Labour Market Trends by Heckley [2005:138] identifies five categories of jobs that are considered to be central to outsourcing and off-shoring of contact centres using the most recent SOC 2000 occupations. He argues that this will circumvent the definition problems associated with industry classifications because 'looking at employment by occupation has the benefit of ignoring sectoral definitions'.

The relevant occupations as shown in table two include call centre agents and operators, and customer care occupations, as well as ICT managers, software professionals and IT technicians. The data is provided through special access to the most recent Labour Force Survey (LFS) for 2005 which is collected using a sample survey of households that provides reasonable estimates of employment 
characteristics at least down to regional or sub-regional levels (data is available below this but accuracy is impaired by reduced sample sizes).

\section{(Table 2)}

Clearly, with the exception of call centre agents, one cannot assume that all of these workers are associated specifically with customer care using contact centre technologies and methods. It is therefore not surprising that the total of all workers total over one million for the UK. However, even the orders of magnitude in this data for call centre agents $(87,000)$ far exceeds the numbers recorded in official employment data for 2003 as reported above (25,112). Furthermore, detailed inspection of definitions of occupations described as 'call centre agent' and 'customer care' reveals considerable overlap. Customer care occupations will include, for instance, such job titles as 'customer care adviser' and 'customer service assistant'. Heckley (2005: 379) argues, in fact, that these two categories 'appear to be one and same thing'. These two categories combined show call centre employment nationally to be approaching 400,000 which, Heckley suggests, is a reasonable estimate of employment in call centres. Other independent assessments of the total employment in UK call centres show estimates generally above 400,000 [Datamonitor 2004 ${ }^{1}$ ].

These figures do not quite reach the levels indicated by the method used by ContactBabel which exceeds 800,000. However, the totals derived from the LFS are of the same order of magnitude as the 'number of seats' identified $(529,000)$ and some of the differences may be caused by varying methods for quantifying part time workers which represent a high proportion of the total in some call centres.

\footnotetext{
${ }^{1}$ see also www.business-strategies.co.uk
} 
ContactBabel also relied initially on the UK Contact Centre Operations Directory which may include a higher proportion of contact centre operation that are not 'freestanding' but co-located with other operations within the same firm. Also, the latter may adopt a wider definition of what constitutes a contact centre job by including all ancillary and support workers who do not fall under managerial and technical occupations. Given these caveats, it does not seem unreasonable to assume that up to 800,000 jobs may be directly dependent upon contact centres.

\section{THE CONTACT CENTRE INDUSTRY IN NORTH-WEST ENGLAND}

Contactbabel [2005] identified 540 contact centres located in the NW region. Of these, a large majority are located in the larger urban centres within Greater Manchester (240) and Merseyside (100) but there has been significant growth recently also in adjacent areas of Cheshire (90) and Lancashire (85). Contact centres however are under-represented in Cumbria (25). In terms of number of jobs, the spatial pattern is even more highly concentrated in the "city regions" of Greater Manchester (55,976); Merseyside (29,528); and Lancashire (23,528).

Again, ContactBabel indicates that, across the UK as a whole, fifteen percent of all contact centre employees are associated with financial services, fourteen percent with retailing and distribution, and twelve percent with motoring, transport and travel. These are also prominent 'vertical markets' associated with contact centres in the NW region, but even the manufacturing sector is prominent in this region (14\% of all regional employment in contact centres). 
This data has also been used by ContactBabel to estimate the proportion of regional employment in each sector that can be accounted for by contact centre activities. This has been achieved by expressing the aggregate employment in NW contact centres as a percentage of the total in each sector drawn from official statistics. The results of this should perhaps be regarded with caution, especially for sectors with low employment counts where differences in classification between the two data sources could produce spurious results. The data generally confirms expectations that contact centre employment accounts for a relatively high proportion of regional employment in finance, IT, telecommunications and utilities. In general, there are reasons to suggest that these figures are minimum estimates, given that a large number of call centres are classified under 'outsourcing' for which there is no equivalent SIC code for comparison.

Contrary to some expectations, recent empirical work conducted by ContactBabel [2005] appears to show strong growth in employment in contact businesses. During 2004, it is estimated that the number of agent position increased on the previous year by ten percent in Cheshire, around five percent in Lancashire and Greater Merseyside, and by four percent in Greater Manchester and Cumbria. Overall in the NW region, the growth of contact centre employment reached around 8.7 percent.

In some parts of the NW Region, this data suggests that employment in contact centres has grown by as much as ten percent. There has also been growth in every sub-region in terms of both numbers of agent positions and staff employed. Even in the major conurbations where the number of contact centres has been static or in slight decline, surviving businesses appear to have absorbed considerably more 
employment than has been lost in business closures. Changes in the Cheshire subregion also seems to indicate growth in contact centre employment in locations outside Greater Manchester which currently has the largest concentration of contact centre businesses in the region.

Fortunately, the analysis reported by Heckley [2005] provides some corroborating evidence of growth in the UK contact centre industry. Using data on 'IT and call centre occupations’ from the Labour Force Survey, Heckley shows that there has been growth in these categories nationally between 2001 and 2005 but this growth has occurred unevenly across the regions with strongest absolute performances in North West and South West regions (see table three). The data also shows that London, the South East generally as well as Wales have been relatively static. Heckley also demonstrates that employment growth in the UK is fairly consistent with other national economic indicators for the sector. In particular, the UK currently has a trade surplus in services and this surplus appears to have been maintained over time between 1994 and 2004. Imports of 'IT-enabled’ services may have increased, but its 'exports have increased just as fast' [Heckley 2005: 378].

\section{(Table 3)}

To conclude this section, available evidence appears to show that contact centres provide very significant employment in the UK and in the NW region. Estimates range from around 420,000 up to higher estimates around 800,000 , depending on definition and methods of counting workers. These workers are also found across a very wide range of sectors including prominently finance, utilities, computing and retailing as well as manufacturing. As regards change over time, the evidence 
presented appears to show that, despite media interpretation of job losses arising from off-shoring, expansion of the activity generally seems sufficient to enable employment growth in UK call centres alongside continued off-shoring. Growth in employment has been particularly focused in the NW region.

These data suggest that there may still be employment growth potential in contact centre businesses in spite of media attention given to the off-shoring phenomenon. Several sources of evidence all point to the conclusion that contact centre activity has been expanding in recent years and that the rate of growth has been sufficient to accommodate domestic growth in employment as well as increases in off-shoring. This is evident not only in employment trends identified by ContactBabel, but also by analysis of occupation data [Heckley, 2005] and the growth of both import and export values in international trade [Abramovsky et al., 2004; Abramovsky and Griffith 2005].

\section{CHANGE IN THE CONTACT CENTRE INDUSTRY AND REGIONAL ECONOMIC STRATEGY}

These conclusions drawn from recent data need careful consideration in the context of regional economic policy making in the UK where there has been a tendency to dismiss contact centre activities as incompatible with the objective of raising the levels of labour productivity in the regions by targeting higher value-added activities. The North West Regional Development Agency (NWRDA) has recently published its Regional Economic Strategy (RES) that covers headline themes on business, skills 
and employment, regeneration, infrastructure and quality of life. Under the business theme, the aim is to 'assist the creation, development and attraction of competitive, high value activities and profitable businesses within a culture of enterprise and innovation' (emphasis added). A key factor influencing the RES concerns interpretations of the relative scale of the region's economy as measured by Gross Value Added (GVA). There is an assumption that there is a 'GVA gap' between the NW region and UK averages that particularly affects service industries. In other words, the strategy is constructed on the assumption that some services, and contact centres in particular, appear to have below average wages and salaries and/or below average levels of operating surplus or profitability compared to other activities.

Given the evolution of regional economies across the UK and the roles assigned to regions by past phases of development, this in not an unexpected observation nor should it necessarily be regarded as a criticism of service businesses in the regions. One would not expect, for instance, that salaries and levels of profitability of financial service activities based in Greater Manchester would be on a par with those in London and the South East where living costs are higher and businesses tend to compete on an international as well as a national scale. The spatial division of labour in large service organisations will also tend to produce such uneven patterns of development.

The strategic response to this observation in the RES appears to be that this GVA gap needs to be (and indeed can be) narrowed and even closed and that there is a need to focus on sectors in regions that have the potential to generate high levels of GVA per worker (or growth in GVA per worker). Particular reference is made in this context to the application of science, the expansion of research and development activities and 
promotion of so-called 'knowledge-based' industries. The driving logic of the arguments outlined above is stated explicitly in determining the definition of 'developing sectors' within which the strategy states that there will be 'focussed development of new and higher value businesses’ [RES: 11].

It is a common perception that contact centres generate low levels of GVA per worker. This view is prominent in the report prepared for NWRDA by Regeneris [2005: 64] which makes recommendations on the target sectors contained in the RES. The Regeneris report states explicitly that 'many of the new jobs created in traded services sectors are quite probably ‘call centre' type jobs which are relatively low paid and low GVA generating'. A key element in the GVA calculation involves wages and salaries. Due to the relatively simple division of labour within contact centres, levels of wages and salaries are clearly structured. This can be seen in table four which shows salaries for new and experienced agents, team leaders and centre managers. The average salary of agents tends to vary regionally between $£ 12 / 14,000$ while the rates for team leaders average around $£ 17 / 18,000$.

\section{(Table 4)}

This data from ContactBabel can be compared with levels of gross annual pay for full time employees in a range of occupations in the NW Region derived from the 2004 Annual Survey of Hours and Earnings [National Statistics, 2004]. Table five confirms general impressions that contact centre salaries (mainly included under customer service occupations) tend to be lower than for other types of service occupations such as secretarial and administrative work. It should be noted, however, that salaries in contact centres are by no means the lowest category; the data indicates 
that salaries in general sales and caring occupations have lower levels of remuneration. Patterns of change between 2003 and 2004 also show that the gap between salaries in contact centres and secretarial occupations has been closing.

\section{(Table 5)}

While data seems to confirm relatively low salaries for call centre occupations, the assumption that this means that contact centres have little to contribute to the achievement of GVA targets in the RES could be challenged. It has been recognised for some time that labour markets in many regions that are characterised by concentrations if high technology or knowledge-intensive businesses tend to be segmented and polarised [Hall and Markusen, 1985; Massey, Quintas and Wield, 1992]. These regions are partly sustained by the co-existence of high paid scientific work alongside a relatively low wage service economy and a highly competitive graduate labour market. This suggests that high GVA activities are sustained, in part, by direct or indirect local linkages with lower GVA service activities. Similarly, it could be argued that greater efficiency in local contact centre businesses may support and help to sustain high GVA businesses in similar or related sectors.

Recent growth in contact centre employment, however, may have another consequence, in that the tightness of labour markets in the major conurbations may increase rates of attrition and cause decision makers in the industry to consider relocation or expansion in smaller labour markets elsewhere. There could be opportunities to work with these businesses to ensure any 'overspill' benefits are retained in the region by promoting contact centre locations in smaller towns and cities. This would be consistent with the objectives of the RES to diversify the 
economies of smaller cities that have 'few economic drivers' as in Blackpool, Barrow, West Cumbria and East Lancashire.

These spatial differences in the density of contact centre businesses are reflected not only in the numbers of workers in different locations, but also in spatial variations in salaries. Table six shows that there are wage differentials for all grades of workers between Greater Manchester and smaller towns and cities in Lancashire and, in particular, in Cumbria. These data suggest that there may be a good business case for some decentralisation within the region and that this could be harnessed to the benefit of regeneration in more peripheral towns and cities in the region.

\section{(Table 6)}

\section{CONCLUSION}

This paper has shown that, despite recent publicity over outsourcing and off-shoring, published data appears to suggest that employment in contact centres in the UK is continuing to expand and forecasts suggests that this is likely to continue at least through to 2008 [DTI, 2004]. Growth in employment is particularly strong in the NW region. The buoyant global market for these types of services is also evidenced through analyses of UK international trade. It is also shown that employment in contact centres serve a very wide range of markets and industries. In structural terms, therefore, contact centres cut across conventional definitions of 'industries'. Despite evidence of continued employment growth, the debate about the impact of off-shoring has drawn attention to some of the competitive issues that are faced by UK-based 
specialist contact centres and also by firms and organisations that adopt these methods of dealing with customers within the context of their business.

The Regional Economic Strategy highlights the sectors that are intended as targets for development. This list currently makes no reference to contact centres, although many of the sectors identified represent important product-markets that make use of contact centres. It is argued that a narrow focus on 'high GVA' activities ignores some of the complexities and inter-linkages that exist regionally between high and low GVA activities. In this regard, improved efficiency and quality in the provision of customer contact services within the region could enhance levels of productivity in a wide range of related industries and services that are more readily recognised for their capacity to produce growth in GVA per worker. 
TABLES.

Table 1: Employment under "call centre activities" in 2003 SIC code 74.86

\begin{tabular}{|l|c|c|c|c|c|c|c|c|c|}
\hline Region & $\begin{array}{c}\text { Male } \\
\text { Full } \\
\text { Time }\end{array}$ & $\begin{array}{c}\text { Male Part } \\
\text { Time }\end{array}$ & $\begin{array}{c}\text { Female } \\
\text { Full } \\
\text { Time }\end{array}$ & $\begin{array}{c}\text { Female } \\
\text { Part } \\
\text { Time }\end{array}$ & Male & Female & Total & $\begin{array}{c}\text { Full } \\
\text { Time }\end{array}$ & $\begin{array}{c}\text { Part } \\
\text { Time }\end{array}$ \\
\hline North West & 2,122 & 287 & 1,825 & 1,111 & 2,409 & 2,937 & 5,346 & 3,947 & 1,399 \\
\hline $\begin{array}{l}\text { Yorkshire \& } \\
\text { Humberside }\end{array}$ & 1,593 & 222 & 614 & 531 & 1,815 & 1,145 & 2,959 & 2,206 & 753 \\
\hline Eastern & 710 & 93 & 811 & 436 & 802 & 1,247 & 2,049 & 1,520 & 529 \\
\hline London & 332 & 34 & 207 & 29 & 365 & 236 & 602 & 539 & 63 \\
\hline South East & 1,455 & 159 & 563 & 248 & 1,614 & 810 & 2,424 & 2,017 & 407 \\
\hline Total & 10,721 & 1,387 & 8,821 & 4,183 & 12,109 & 13,004 & 25,112 & 19,542 & 5,570 \\
\hline
\end{tabular}

Source: 2003 Annual Business Enquiry (ABI) accessed via NOMISWEB

Table 2: Employment in IT and Call Centre Occupations in the UK, Spring 2005

\begin{tabular}{|l|l|c|}
\hline SOC Code and Occupation & Related types of job title & Thousands \\
\hline 1136, ICT Managers & $\begin{array}{l}\text { Computer Manager } \\
\text { IT Manager } \\
\text { Systems Manager } \\
\text { Telecom Manager } \\
\text { Data Processing Manager }\end{array}$ & 271 \\
\hline 3132, Software Professionals & $\begin{array}{l}\text { Analyst programmer } \\
\text { Computer programmer } \\
\text { Software engineer } \\
\text { Systems Analyst } \\
\text { Systems designer }\end{array}$ & 124 \\
\hline 3131, IT operations technicians & $\begin{array}{l}\text { Computer operator } \\
\text { Database manager } \\
\text { IT Technician } \\
\text { Systems administrator }\end{array}$ & 276 \\
\hline 7211, Call centre agents and operators & $\begin{array}{l}\text { Answer line operator } \\
\text { Sales order clerk } \\
\text { Telephone advisor }\end{array}$ & 87 \\
\hline 7212, Customer care occupations & $\begin{array}{l}\text { Customer care adviser } \\
\text { Customer liaison officer } \\
\text { Customer service assistant }\end{array}$ & 287 \\
\hline Total & & 1046 \\
\hline
\end{tabular}

Source: data from Labour Force Survey reported in Heckley (2005) 
Table 3: Change in employment in occupations related to IT and Call Centres

\begin{tabular}{|l|c|c|c|c|}
\hline Region & $\begin{array}{c}\text { Spring 2001 } \\
\text { ('000) }\end{array}$ & $\begin{array}{c}\text { Spring 2005 } \\
(' 000)\end{array}$ & $\begin{array}{c}\text { Change } \\
(' 000)\end{array}$ & $\begin{array}{c}\text { \% Change } \\
2001-2005\end{array}$ \\
\hline North East & 33 & 42 & 9 & 27.3 \\
\hline North West & 106 & 127 & 21 & 19.8 \\
\hline Yorkshire \& Humb & 69 & 79 & 10 & 14.5 \\
\hline East Midlands & 58 & 71 & 13 & 22.4 \\
\hline West Midlands & 63 & 74 & 11 & 17.5 \\
\hline East of England & 95 & 102 & 7 & 7.4 \\
\hline London & 153 & 157 & 4 & 2.6 \\
\hline South East & 183 & 180 & -3 & -1.6 \\
\hline South West & 73 & 90 & 17 & 23.3 \\
\hline Wales & 33 & 32 & -1 & -3.0 \\
\hline Scotland & 75 & 83 & 8 & 10.7 \\
\hline Northern Ireland & 12 & 9 & -3 & -25.0 \\
\hline
\end{tabular}

Source: author's calculations from Heckley (2005)

Table 4: Average Salary levels for Contact Centre workers, 2004

\begin{tabular}{|l|c|c|c|c|}
\hline & North West & North East & Scotland & $\begin{array}{c}\text { Great } \\
\text { Britain }\end{array}$ \\
\hline Salaries - new agent & $£ 12,046$ & $£ 12,955$ & $£ 11,049$ & $£ 12,945$ \\
\hline $\begin{array}{l}\text { Salaries - experienced } \\
\text { agent }\end{array}$ & $£ 13,449$ & $£ 14,164$ & $£ 12,472$ & $£ 13,891$ \\
\hline Salaries - team leader & $£ 17,130$ & $£ 18,409$ & $£ 16,360$ & $£ 17,964$ \\
\hline $\begin{array}{l}\text { Salaries - call centre } \\
\text { manager }\end{array}$ & $£ 26,458$ & $£ 26,500$ & $£ 25,625$ & $£ 27,166$ \\
\hline
\end{tabular}

Source: ContactBabel 2005

Table 5: Gross annual pay for full-time employee jobs in NW Region $2004(£)$

\begin{tabular}{|l|c|c|c|}
\hline & Median & Mean & \% change \\
\hline Managers and senior officials & 30,755 & 37,068 & 5.3 \\
\hline Professional occupations & 30,360 & 32,714 & 2.6 \\
\hline Associate professional and technical & 24,676 & 27,374 & 6.1 \\
\hline Skilled trades & 20,790 & 21,210 & 4.6 \\
\hline Process, plant and machine operatives & 18,341 & 19,258 & 2.0 \\
\hline Administrative Occupations & 16,115 & 17,192 & 4.8 \\
\hline Secretarial And Related Occupations & 14,973 & 16,370 & -0.9 \\
\hline Elementary occupations & 14,706 & 15,365 & 2.3 \\
\hline Leisure and other personal services & 14,560 & 15,198 & 4.5 \\
\hline Customer service occupations & 14,220 & 14,910 & 3.6 \\
\hline Caring personal service occupations & 13,512 & 13,610 & 2.9 \\
\hline Sales Occupations & 12,344 & 14,083 & -0.6 \\
\hline
\end{tabular}

Annual survey of hours and earnings (ASHE) accessed via National Statistics 
Table 6: Average Salary levels for Contact Centre workers by sub-region, 2004

\begin{tabular}{|l|c|c|c|c|c|c|}
\hline & $\begin{array}{c}\text { Cheshire \& } \\
\text { Warrington }\end{array}$ & Cumbria & $\begin{array}{c}\text { Manchester } \\
\text { CC Salford }\end{array}$ & $\begin{array}{c}\text { Rest of } \\
\text { Greater } \\
\text { Manchester }\end{array}$ & Lancashire & Merseyside \\
\hline New agent & $£ 12,482$ & $£ 10,385$ & $£ 12,544$ & $£ 11,980$ & $£ 11,790$ & $£ 12,080$ \\
\hline $\begin{array}{l}\text { Experienced } \\
\text { agent }\end{array}$ & $£ 13,583$ & $£ 12,382$ & $£ 13,982$ & $£ 12,830$ & $£ 12,890$ & $£ 12,760$ \\
\hline Team leader & $£ 18,278$ & $£ 16,560$ & $£ 18,853$ & $£ 17,084$ & $£ 16,930$ & $£ 17,160$ \\
\hline $\begin{array}{l}\text { Call centre } \\
\text { manager }\end{array}$ & $£ 26,818$ & $£ 24,985$ & $£ 29,320$ & $£ 26,550$ & $£ 26,328$ & $£ 26,504$ \\
\hline
\end{tabular}

Source: ContactBabel, 2005 


\section{REFERENCES.}

Abramovsky, L. and Griffith, R. (2005): Outsourcing and Off-shoring of Business Services: how important is ICT? - Institute for Fiscal Studies, London: UCL.

Abramovsky, L.; Griffith, R. and Sako M. (2004): Off-shoring of business services and its impact on the UK economy, Advanced Institute of Management Research, Briefing Notes, November 2004

Belt, V.; Richardson, R. and Webster, J. (2002): Women, social skill and interactive service work in telephone call centres, New Technology, Work and Employment, 17(2), pp.20-34.

Belt, V. and Richardson, R. (2005): Social labour, employability and social exclusion: Pre-employment training for call centre work, Urban Studies, 42(2), pp. 257 - 270.

Bishop, P.; Gripaios, P. and Bristow, G. (2003): Determinants of call centre location: some evidence for UK urban areas. Urban Studies, 40(13), pp. 2751-2768.

Contactbabel (2004): UK contact centre in 2004: The State of the Industry, 3rd edition, Sedgefield: ContactBabel Reports

Contactbabel (2005): Call Centre in the North West: Baseline Research, Preston: CallNorthWest. 
CM Insight (2001): Seizing the off-shore opportunity, Weybridge: CM Insight Research Documents.

Datamonitor (2004, 2005): Call Centres Industry Profile: United Kingdom, London: Datamonitor

Department for Trade and Industry (2004): The UK Contact Centre Industry. A Study, Report by CM Insight, ContactBabel, and The Call and Contact Centre Association (CCA) on behalf of the UK Department of Trade and Industry, May 2004.

Hall, P. and Markusen, A. eds. (1985) Silicon Landscapes, London: Unwin Hyman.

Heckley, G. (2005): Off-shoring and the labour market: the IT and call centre occupations considered, Labour Market Trends, 113(9), pp. 373-385

Jones, G. (2003): Economic Statistics and the Standard Industrial Classification, Economic Trends - Office for National Statistics, 593, pp. 2-28

Massey, D.; Quintas, P. and Wield, D. (1992): High Tech Fantasies: Science Parks in Society, Science and Space, London: Routledge.

Newing R. (2004): Off-shore or Off-target: a future for UK call centres, Dublin: Intervoice Ltd. (www.intervoice.com) 
National Statistic, (2004): Annual Survey of Hour and Earnings, London: Official Labour Market Statistics.

North West Development Agency, (2006): Northwest Regional Economic Strategy, Official Document provided by the North West Development Agency, Warrington.

OMIS (2003): Best location for contact centres- Second Biennial Survey, OMIS Research, Bambury: Martin House.

Puttock, M. (2004): Offshore means being of strategy, ICT Group News, ICT Europe (www.ictgroup.com/eurotel/articles/puttock_off-shore.html.)

Regeneris (2005): North West Economic Baseline: Final Full Report, Baseline Report for the North West Development Agency, Warrington.

Richardson R. and Marshall J. N. (1996) Teleservices, Call Centre and Urban and Regional Development, The Service Industries Journal, 19(1), pp. 96-116.

Richardson, R.; Belt, V. and Marshall J.N. (2000): Taking calls to Newcastle: The regional implications of the growth in call centres. Regional Studies, 34(4), pp. 357369.

Richardson, R. and Belt, V. (2001): Saved by the bell? Call centres and economic development in less favoured regions. Economic and Industrial Democracy, 22(1), pp. 67-98. 


\section{ACKNOWLEDGEMENTS}

This research was supported by funding from CallNorthWest (CNW), an initiative funded by North West Development Agency (NWDA). The authors are grateful to staff at CNW for their support and advice in preparing this article. Particular thanks are due to Bob Hale, Giles McLelland and Rob Arran. An earlier version of this paper was presented at the Inaugural UK Contact Centre Seminar, CallNorthWest, at the $28^{\text {th }}$ National Conference of the Institute for Small Business \& Entrepreneurship (ISBE), 1-3 November 2005, Blackpool, UK and to the Centre for Regional Economic Development (CRED, UCLan) Seminar Series in Carlisle on $9^{\text {th }}$ November 2005. Thanks are due to these audiences for their comments and feedback. 